\title{
THE POLITICAL SYSTEM OF SOCIETY: FEATURES AND PROSPECTS OF DEVELOPMENT IN UKRAINE
}

\section{Olha Chepik-Trehubenko}

\section{INTRODUCTION}

The social order of each country implies the existence of such a component as political system. At present, Ukrainian society is undergoing a stage of transformation of the political system, moving towards becoming an equal actor in the society-state relationship, thus developing the characteristic qualities of civil society. The multifunctionality of such a cognitive structure as the political system of society has caused the pluralism of opinions in the approaches to its interpretation, in particular from the point of law. The information component is key in the development of the political system of society.

Despite the significant contribution of such domestic and foreign scientists as O. Babkina, M. Baimuratov, E. Batalov, O. Batanov, P. Bieglov, Y. Bytiak, V. Bogatyriov, I. Butko, A. Vengerov, D. Vydrin, B. Gaievskyi, V. Helman, V. Horbatenko, V. Hrygoriev, O. Danylian, O. Dzioban, O. Demianchuk, M. Idrisova, D. Easton, V. Kampo, G. Klimova, M. Kononchuk, S. Korzh, V. Kostytskyi, S. Maksymov, M. Marchenko, L. Nalyvaiko, M. Orzikh, M. Panov, O. Petryshyn, V. Pohorilko, O. Proskurina, P. Rabinovych, O. Rudakevych, Y. Riaboi, P. Sas, H. Sashchuk, S. Seriohina, O. Skakun, V. Tatsii, Yu. Todyka, V. Trushyna, V. Khropaniuk, Y. Shemshuchenko, I. Shtuka, V. Yakoviuk, I. Yarulin and others, who have researched individual issues of the political system of society, there is a lack of a modern and effective scientific theoretical approach to understanding this category and features of the current state and further development, which negatively affects the formation of civil society and the rule of law in Ukraine.

The modernization of the political system of Ukrainian society in the modern era is one of the ambiguous phenomena, which results in the process of changing not only the political course of the state, but practically the whole substantive part of the political system of society. At the present stage, when Ukraine is getting rid of the remnants of the past and direct total interference in all spheres of society, it is important to analyze the nature and content of modernization of the political system of society, the features of its formation process and the prospects for its further development. For more than twenty years, Ukrainian society has been in a state of systemic transit - the transition to a new quality level of all spheres of its activity. 


\section{Concepts and features of the political system of society}

Every society, regardless of its level of development, is undergoing some degree of political and legal transformation. This is characteristic of both highly developed (civil) and the underdeveloped (tribal) society ${ }^{1}$. The problem of interaction between political existence and political consciousness has always interested scientists. But studies of the relationship between the ideal and the real in politics become relevant at the turning points of history, when the processes of democratization include broad sections of the population in socio-political life ${ }^{2}$. Since these issues need legal regulation, there is a need to study them from the standpoint of science of theory of state and law.

Today, the inability of political party leaders to consolidate and make important compromise decisions should be acknowledged as a negative phenomenon in the political system of society. The main transformational measures in the political system of society should be development of the Ukrainian political elite; harmonization of relations between all subjects of the political system of society; reform and adjustment of national legislation with international standards. The effectiveness of the political system ensures the proper functioning of the social, economic, spiritual and cultural spheres.

Each system of society is a single, orderly system of components, the interaction of which causes the emergence of a different quality. The political system is no exception. The term "political system of society" provides an opportunity to identify and characterize the political interests of different actors.

Confusion in legal terminology on the understanding of the term "political system of society" needs to turn to theoretical developments in this field.

The category "political system of society" has been introduced into the scientific field relatively recently, at the stage of development of society, when political parties, public associations, movements began to operate alongside state institutions. Exploring the issues of the political system of society, L. Nalyvaiko concludes that in a broad sense it is a set of interrelated and interdependent political institutions stipulated by the Constitution and laws of Ukraine, which exercise power in society, regulate political relations, political activity, ensure stability and order in accordance with the achieved level of political culture. The scientist also emphasises that understanding the political system of society as a set of state and non-state institutions fetishizes

\footnotetext{
${ }^{1}$ Mynjkovych-Slobodjanyk O.V. (2015) Pravova ta politychna kuljtura v umovakh politykopravovoji transformaciji suspiljstva [Legal and political culture in the conditions of political and legal transformation of society]. Chasopys Kyjivsjkogho universytetu prava, no. 4, p. 28.

${ }^{2}$ Ishmanova G.D. (2007) Struktura politicheskoy kul'tury i proyavlenie ee komponentov v sotsial'no-politicheskoy zhizni sovremennoy Rossii [The structure of political culture and the manifestation of its components in the socio-political life of modern Russia] (PhD Thesis). Ufa: Bashkirskiy gosudarstvennyy universitet, p. 46-47.
} 
the state as a subject of the political system, thus denying the priority role of the people. After all, the political system is usually called the political system of society, not the political system of the state $^{3}$. This approach is of great practical importance for understanding the political sphere of society and the importance of active public in it. In the rule of law, the primary tasks of the political system of society are to ensure public order, to create conditions for political stability, and to harmonize important interests for society.

The emergence of the term "political system" was conditioned by the isolation of a set of different political phenomena into a certain integrity against the background of the rest of society ${ }^{4}$. In legal science, domestic studies of the political system of Ukrainian society began in the $60 \mathrm{~s}$ of the $20^{\text {th }}$ century". In general, the term "political system" was hardly used in the scientific works of domestic scientists until the $70 \mathrm{~s}$ of the $20^{\text {th }}$ century. Instead, the term "political organization of society" was applied ${ }^{6}$. In Soviet times, the political system was regarded, as a rule, formally, symbolically, as a collection of political organizations ${ }^{7,8}$.

The political system does not exist separately from the external environment with which it interacts with aid, carrying out "transformation" within itself. This makes it possible to speak of the implementation of the political system and, accordingly, of its internal processes in some general plane 9 .

Today in the scientific literature, in particular the legal, political systems of society are offered to understand as follows: the political system is an integrated set of state and non-state social institutions that exercise power, manage the affairs of society, regulate the relationship between citizens, social groups, nations, states, states stability of society, a certain social $\operatorname{order}^{10}$;

\footnotetext{
${ }^{3}$ Nalyvajko L.R. (2009) Derzhavnyj lad Ukrajiny: teoretyko-pravova modelj [State system of Ukraine: theoretical and legal model]: monoghrafija. Kharkiv: Pravo, p. 38-40.

${ }^{4}$ Ghotun A. (2011) Osnovni koncepciji doslidzhennja komunikaciji v politychnij systemi suspiljstva [Basic concepts of communication research in the political system of society]. Politychnyj menedzhment, no. 1, p. 75.

5 Nedbajlo P.O. (1967) Politychna orghanizacija suspiljstva [Political organization of society]. Kyjiv: In-t derzhavy i prava AN Ukrajiny, Naukova dumka.

${ }^{6}$ Il'inskiy I.P. i dr. (1975) Politicheskaya organizatsiya i upravlenie obshchestvom pri sotsializme [Political organization and management of society under socialism]. Moskva: Mysl'

7 Butko I.P., Kornijenko M.I. (1988) Politychna systema radjansjkogho suspiljstva [The political system of Soviet society]. Kyjiv: Radjansjka shkola, p. 23.

${ }^{8}$ Nalyvajko L.R. (2009) Derzhavnyj lad Ukrajiny: teoretyko-pravova modelj [State system of Ukraine: theoretical and legal model]: monoghrafija. Kharkiv: Pravo, p. 38-40.

${ }^{9}$ Ghotun A. (2011) Osnovni koncepciji doslidzhennja komunikaciji v politychnij systemi suspiljstva [Basic concepts of communication research in the political system of society]. Politychnyj menedzhment, no. 1, p. 76.

${ }^{10}$ Keljman M.S., Murashyn O.Gh., Khoma N.M. (2003) Zaghaljna teorija derzhavy ta prava [General theory of state and law]: pidruchnyk. Ljviv: Novyj svit-2000, p. 145.
} 
component, organic part of the social system, which includes the totality of different social subjects and institutions, united by participation in the political life of society, the various forms of political relations and relationships in which it is realized and the core of which are relations about state power and the results of political activity ${ }^{11}$; set of political institutions and organizations, political activity, political relations, political norms, principles and traditions, political consciousness, culture and media in their interaction, reflecting the interests and will of the social associations that exercise political power, struggle for its exercise within rights through the state ${ }^{12}$; holistic, orderly set of political institutions, political roles, relations, processes, principles of political organization of society, subordinate to the code of political, social, legal, ideological, cultural norms, historical traditions and principles of political regime of a particular society ${ }^{13}$; holistic, orderly set of political institutions, political relations, processes, principles of political organization of a society, subject to certain political, social, legal, ideological, cultural norms, historical traditions and principles of political regime of a particular society $^{14}$; a comprehensively organized and orderly set of political institutions, which are intended to carry out their activities on the normative and legal basis and to promote the legitimacy of political power in the state, as well as to provide social and spiritual guarantees for the development of society ${ }^{15}$. The concept of a political system is multidimensional in nature, the content of which are organizational and political institutions.

In its system, the phenomenon under study includes the organization of political power, relations between society and public authority.

Successful development of Ukraine as a European democratic state is impossible without realizing the importance of introducing effective ways of modernizing the political system of society.

${ }^{11}$ Ghoncharov P.K. (2009) Polytycheskaja systema rossyjskogho obshhestva v uslovyjakh postsovetskogho tranzyta: socyologhycheskyj analyz [The Political System of Russian Society in Post-Soviet Transit Conditions: A Sociological Analysis] (PhD Thesis). Moskva: Ros. akad. ghos. Sluzhby, p. 19-20.

${ }^{12}$ Volynyka K.Gh. (2003) Teorija derzhavy i prava [The theory of state and law]: navch. posib. Kyjiv: MAUP, p. 23.

13 Aznagulova G.M. (2010) O vzaimodeystvii pravovoy i politicheskoy system [On the interaction of legal and political systems]. Yurisprudentsiya, T. 20, vol. 4, p. 6.

14 Jusov A.V. (2008) Politychna systema suchasnogho suspiljstva: ponjattja, struktura, funkciji [The political system of modern society: concepts, structure, functions]. Derzhava $i$ pravo. Jurydychni i politychni nauky, vol. 41, p. 113.

${ }^{15}$ Nazarenko O. (2012) Politychna systema suspiljstva: sutnistj, osnovni rysy, funkciji [Political system of society: essence, main features, functions]. Visnyk Kyjivsjkogho nacionaljnogho universytetu imeni Tarasa Shevchenka. Jurydychni nauky, vol. 94, p. 87. 
Based on this analysis, it is appropriate to define the term "political system of society" as a coherent and complex set of elements, the tasks of which are aimed at achieving and ensuring the stable functioning of society through their effective interaction and implementation of political functions in accordance with the fundamental principles of law.

Among the features of the political system of society are the following: the integrity and complexity of the elements; conditional independence; internal and external relationships; static and dynamic character; normative regulation.

\section{Institutions of the political system of society and their characteristics}

Political parties that really represent society are an indispensable element of representative democracy ${ }^{16}$. One of the basic principles of such parties is openness to dialogue with the public and with other political parties in the country.

In modern democratic states, the political systems of society seek to balance in every possible way, taking into account the interests and needs of all subjects.

As of January 1, 2019, 352 political parties have been registered in Ukraine in accordance with the procedure established by law ${ }^{17}$. At the same time, the overwhelming majority of parties do not engage in active political activity; new parties are mostly registered for further "commercial use" 18 .

An integral part of the political system of any democratic society is the functioning of the opposition and the basis for the development of civil society. In the system of political relations, the opposition performs significant positive functions: it promotes the separation, reflection and generalization of the interests of population groups that are not satisfied with the activities of different branches of government in the centre and regions ${ }^{19}$. However, it is not necessary to exaggerate the positive role of the opposition, since individual opposition groups used democratic norms and procedures as a means of protecting the narrowminded interests and ambitious claims of their leaders for national representation $^{20}$. The effectiveness of political opposition is determined by a

${ }^{16}$ Grin'ko V.V. (2006) Sotsial'no-politicheskaya sistema obshchestva kak elektoral'naya model' [Socio-political system of society as an electoral model]. Sotsiologiya vlasti, no. 3, p. 150.

${ }^{17}$ Vidomosti z sajtu Ministerstva justyciji Ukrajiny [Information from the website of the Ministry of Justice of Ukraine] https://minjust.gov.ua/m/4561

${ }^{18}$ Jakymenko Yu., Bychenko A., Zamjatin V. ta in. Ukrajina 2016-2017: oznaky proghresu ta symptomy rozcharuvannja (analitychni ocinky) [Ukraine 2016-2017: signs of progress and symptoms of disappointment (analytical estimates)]. Kyjiv.

${ }_{19}$ Morarj M.V. (2017) Politychna opozycija jak nevid'jemnyj element politychnoji systemy suspiljstva [Political opposition as an integral part of the political system of society]. Ghileja, vol. 118.

${ }^{20}$ Mykhaljchenko M., Kuras I., Rudych F. ta in. (2002) Vzajemodija politychnoji vlady i opozyciji jak politologhichna problema [The interaction of political power and opposition as a political problem]. Suchasna ukrajinsjka polityka i politologhija pro neji. Kyjiv: In-t derzhavy i prava im. V.M. Korecjkogho, p. 26. 
number of factors, in particular: normative and legal regulation, public support for the opposition, and constructiveness of opposition forces.

Accordingly, the processes taking place in the political system have a significant impact on the results of transformations throughout society. The maintenance of Ukraine as an independent state depends on the content of its activity, quality of functioning, coherence of actions of all its subsystems.

Special communication tools are required to maintain a constant connection between policy makers. This is conditioned by the very nature of politics as a collective, complexly organized purposeful activity, a specialized form of communication of people for the realization of group goals and interests that interest the whole society. The collective nature of the goals that are pursued in politics implies a compulsory awareness of the divisions within the collective (states, nations, parties, etc.) and the coordination of activities of people and organizations. All this, of course, is impossible with the direct, contact interaction of citizens and requires the use of special means of information transmission, which ensure the unity of will and focus of actions of a large number of distant people ${ }^{21}$. An effective communication channel between the subjects of the political system and other entities requires permanent improvement of information and communication technologies, since the current state of information and technological support in Ukraine does not correspond to international and advanced achievements in this field.

Among the novelties of domestic legislation in the political sphere of society, the rule on state financing of the statutory activities of political parties deserves special attention. According to the approved changes, the statutory activities of political parties, not related to their participation in the elections of the People's Deputies of Ukraine, elections of the President of Ukraine and local elections, are financed at the expense of the State Budget of Ukraine, as well as the expenses of political parties related to the financing of their election campaigning during the next and early elections of the People's Deputies of Ukraine are reimbursed. The annual amount of state funding for the statutory activities of political parties is set: two hundredths of the minimum wage set for January 1 . It is determined that the right to receive state funding for statutory activity is held by a party whose election list received at least $2 \%$ of the valid votes of voters who took part in the last regular or early elections of the People's Deputies of Ukraine in the national constituency ${ }^{22}$. However, on October 2, 2019, the Verkhovna Rada of Ukraine

${ }^{21}$ Ghotun A. (2011) Osnovni koncepciji doslidzhennja komunikaciji v politychnij systemi suspiljstva [Basic concepts of communication research in the political system of society]. Politychnyj menedzhment, no. 1, p. 78.

${ }_{22}$ Chernoivanenko A.V. (2016) Funkcionuvannja politychnykh partij v Ukrajini: osoblyvosti normatyvno-pravovogho zabezpechennja [Functioning of political parties in Ukraine: features of normative legal support]. Teorija ta praktyka derzhavnogho upravlinnja, vol. 3, p. 70-71. 
cancelled funding for parties that did not overcome the 5\% barrier in elections.

The main task of the law is to reduce the risks of political corruption by introducing comprehensive amendments to the legislation of Ukraine in the field of financing political parties and election campaigning, in particular: reducing the dependence of parties on financing by private donors (oligarchs, industrial-financial groups, and so on); creating conditions for free and fair inter-party competition and the development of new parties through the introduction of state funding for parties; enhancing the transparency of funding for political parties and their local organizations, as well as enhancing the transparency of election campaign funding; imposition of effective, proportionate and efficient sanctions for violations in party financing and election campaigning ${ }^{23}$.

Expert opinions on financing political parties in Ukraine should be provided. V. Taran, in particular, believes that this law will take time to implement it if the parties are more virtuous and not tied to the money received from certain patrons. The expert also emphasised on foreign practice: in Lithuania and Estonia similar changes worked immediately, while in Latvia and Poland there are still problems ${ }^{24}$. The system of state funding of parties is very simple - it assesses the effectiveness of parties by election results and, according to these results, political forces are compensated for their activities. In our country, the financing of political parties needs to be brought to a completely new transparent system. This should be a system of membership contributions, one-off contributions from party members in the election year, etc. Political parties should be financed exclusively from transparent, taxconfirmed funds, according to V. Tsybulko ${ }^{25}$. However, it is important to develop appropriate mechanisms for the legal accountability of political parties for violating the relevant rules of the law.

Moreover, it should be noted that this issue needs further thorough study due to the lack of trust of the citizens of Ukraine in the activities of political parties. As of March 2019, after a sociological survey, 76\% of citizens expressed their distrust.

${ }^{23}$ Zakon pro finansuvannja politychnykh partij iz derzhavnogho bjudzhetu [Law "On financing political parties from the state budget”] https:/uk.wikipedia.org/wiki/ Закон_про_фінансування_політичних_партій_із_державного_бюджету

${ }^{24}$ Chernoivanenko A.V. (2016) Funkcionuvannja politychnykh partij v Ukrajini: osoblyvosti normatyvno-pravovogho zabezpechennja [Functioning of political parties in Ukraine: features of normative legal support]. Teorija ta praktyka derzhavnogho upravlinnja, vol. 3, p. 70.

${ }^{25}$ Derzhavne finansuvannja partij: pljusy ta ryzyky [Public party funding: benefits and risks] https://antikor.com.ua/articles/59246-derhavne_finansuvannja_partij_pljusi_ta_riziki 
Thus, in March 2019, 1.4\% of citizens fully trusted parties, $10.1 \%$ - rather trusted $^{26}$. So, in general, the public is very negative about most parties. The early parliamentary elections in July 2019 had a significant impact on the Ukrainian political party and became unprecedented, with the first opportunity to form a coalition of members of one party (including majority members who are members of the respective party) - a total of $43,16 \%$ of votes.

Despite the recent developments, the political system of society in the sphere of political parties' activity needs significant modernization.

An important area for domestic parties is international cooperation. In particular, the implementation of Ukraine's European integration course requires consolidation of efforts by diplomats and non-governmental policy makers in promoting the country's interests in the European community. Inter-party cooperation has a significant potential in shaping the image of the state favourable for European integration and achieving political support for the country's position in the EU. Promising in this context is the development of links with European transnational parties, which are becoming increasingly influential in Europe $^{27}$.

Sufficient social experience of the developed democracies is convincing evidence that the current political system, in its present form, could not have developed without the influence of the institution of local self-government. The question of the existence and development of the system of local selfgovernment is a dialectical transformation of the whole system of power relations in the country, and its local economic, political and other local and autonomous activity serves as a powerful source of change in these spheres. Under this approach, local self-government should be characterized as a power. But it is a power of a special kind, the power of the people, which has all the necessary capabilities for self-organization in the local territory, without the pressure of strict standards, capable of realizing its control function $^{28}$. In the modern democratic, social-legal state the necessity of formation and development of local self-government is caused by a number of reasons. One of them is the growing importance and strengthening of the role

${ }^{26}$ Rivenj doviry do suspiljnykh instytutiv ta elektoraljni orijentaciji ghromadjan Ukrajiny [The level of trust in public institutions and the electoral orientation of Ukrainian citizens] http://razumkov.org.ua/napriamky/sotsiologichni-doslidzhennia/riven-doviry-do-suspilnykhinstytutiv-ta-elektoralni-oriientatsii-gromadian-ukrainy-2

27 Partijno-ideologhichna strukturyzacija jevropejsjkogho politychnogho prostoru ta mozhlyvosti prosuvannja interesiv Ukrajiny v JeS [Party-ideological structuring of the European political space and opportunities for promoting Ukraine's interests in the EU] http://www.niss.gov.ua/articles/693/

${ }_{28}^{28}$ Trebin M. p. ta in. (2013) Ghromadjansjke suspiljstvo: politychni ta socialjno-pravovi problemy rozvytku [Civil society: political and socio-legal problems of development]: monoghrafija. Xarkiv: Pravo, p. 218. 
of territorial communities. Under the conditions of a political system of a democratic society, the territorial communities, which are the basis and the primary subject of local self-government, play an undeniable role, since they ensure its normal and effective functioning.

The importance of the development of the scientific problems of the place of the territorial community in the political system of society in the present transformational conditions requires comprehensive research. This is due to their mobile nature, dependence of development and essence on changes in state and public life, on political, economic, social and other transformations.

It is the awareness of the importance of the territorial community in the political system of society that significantly updates the search for researchers in this field.

Territorial communities are one of the important institutions of the political system. The concept of territorial community is relatively new to the legal science of Ukraine. Despite the lack of consensus among scientists on the definition of "territorial community", it has received its legislative definition, including in the Constitution of Ukraine. This once again confirmed the importance of this institute. According to the provisions of the Basic Law of the state and the law of Ukraine "On local self-government in Ukraine", a territorial community is residents united by permanent residence within a village, settlement, city, which are independent administrativeterritorial units, or voluntary union of residents of several villages having a single administrative centre. Also, the legislation of Ukraine, in particular in the mentioned legal acts, enshrines a rather wide range of powers of the territorial community in public administration, namely elections of deputies of local councils, village, town and city mayors, local referendums, general meetings (conferences), public hearings initiatives, management of communal property, approval of the programme of socio-economic and cultural development and control of their implementation, etc.

Territorial community in modern conditions acts as a form of social organization of society, a kind of social institution that provides implementation in a certain area of integration policy on the common interests of local residents ${ }^{29}$. An active, influential and advanced civil society is an essential element of any democratic state and plays one of the key roles in implementing urgent social change and good governance, managing public affairs and addressing local issues, developing and implementing effective public policies, asserting the rule of law responsible to the person, solving

${ }^{29}$ Baranovsjka T.M. (2017) Derzhavna polityka rozvytku terytorialjnykh ghromad v Ukrajini [State Policy for Development of Territorial Communities in Ukraine] (PhD Thesis). Kharkiv: Nacionaljna akademija derzhavnogho upravlinnja pry Prezydentovi Ukrajiny, p. 6. 
political, socio-economic and humanitarian problems. The empowerment of the local community in the exercise of local self-government is defined as an important direction in the implementation of the National Strategy for Promoting Civil Society Development in Ukraine for 2016-2020 $0^{30}$. In spite of the thorough regulatory support of the rights of the territorial community, there are still some gaps in their legislative regulation and a number of problems in the mechanism of their implementation.

Since becoming an independent state, Ukraine has developed a system of local self-government, but in its essence it has many Soviet features, which hinders the democratic development of society and the state. Therefore, the current direction of institutional changes in the political system of Ukrainian society is the reform of public authorities at the regional and local levels.

Without a doubt, reforming the system of local self-government to a state that would maximize the interests of citizens in all spheres of life is of utmost importance. According to the majority of experts and practitioners, the main task of reforming the system of organization of power at the local level is the formation of a proper resource base for the realization of the right to local self-government by territorial communities ${ }^{31}$.

The implementation of a series of effective measures will help to establish in Ukraine a democratic model of the political system of the European model, which will allow to ensure in practice the principles of the rule of law, the possibility of real implementation of the constitutional rights of territorial communities, their proper management, the effective functioning of local self-government.

The legal institutionalization of a territorial community is conditioned by the growing role of the territorial community and the need to strengthen legal statehood. The territorial community is an important component of the political system of society and plays a decisive role in the democratization of Ukraine's state system. Further scientific elaborations of this problem are necessary for the prospect of development of local self-government, extension of rights of territorial communities and improvement of the mechanism of their realization, in the conditions of formation of the rule of law and civil society.

${ }^{30}$ Nacionaljna strateghija spryjannja rozvytku ghromadjansjkogho suspiljstva v Ukrajini na 2016-2020 roky [National Strategy for Promoting Civil Society Development in Ukraine for 2016-2020]:Ukaz Prezydenta Ukrajiny vid 26 ljutogho 2016 r. Oficijnyj visnyk Prezydenta Ukrajiny, 2016, no. 7

${ }^{31}$ Pro vnutrishnje ta zovnishnje stanovyshhe Ukrajiny v 2013 roci [On the internal and external situation of Ukraine in 2013]: Shhorichne Poslannja Prezydenta Ukrajiny do Verkhovnoji Rady Ukrajiny. Kyjiv : NISD, 2012, p. 200. 


\section{Political culture as an element of the political system of society}

Political culture is a fundamental component of the political system of society. Political values are dominant in political culture. Political values include: equality, justice, democracy, freedom, socialism, security, state, statism, paternalism, monarchy, peace, etc. Political values are socio-political ideals (freedom, justice, equality, etc.) and political phenomena reflected in consciousness (state, monarchy, statism, etc.). For each subject of political life, the range of significant political phenomena will be different. Therefore, it can be said that political values are the value orientations in the sphere of politics of a particular subject of political life and the objects of these orientations. On the other hand, values that are inherent only in the political culture of these societies are formed in the political culture of different societies. They reflect the general aspirations of the people. Formed under the influence of various factors, including under the influence of the national culture of society, these values are embodied in the minds of the people, determine the general order of their opinions regarding political power, political system, future of the country, define political culture as such. Therefore, more precisely, political values can be defined as extremely general orientations and ideals of society in the socio-political sphere, as well as politically significant social phenomena that are fixed in the mind of people and represent a characteristic feature of general life activity ${ }^{32,33}$.

However, the urgency of the problem now lies in the fact that in Ukraine there has not yet emerged a full-fledged political nation with clearly defined national interests, for which a consensus would emerge both among the elite and among citizens. In these circumstances, the process of Ukrainian state formation is difficult and ambiguous ${ }^{34}$. Thus, in today's reality, in the context of active integration of politics into people's lives, it is urgent and necessary to determine the proper place and role of political culture, since the latter has a fundamental influence on the formation of citizenship and, accordingly, the formation of a democratic state.

However, despite the diversity of political parties and public associations, new associations and parties are emerging in the current political system. The

${ }^{32}$ Djomina O.S. (2014) Politychna kuljtura jak cinnisno-normatyvna systema suchasnogho ukrajinsjkogho suspiljstva [Political culture as a value-normative system of modern Ukrainian society]. Naukovyj chasopys NPU imeni M. P. Draghomanova, vol. 15, p. 149.

${ }^{33}$ Korzh S.A. (2009) Fraghmentarna politychna kuljtura jak vyjav perekhidnogho periodu rozvytku ukrajinsjkogho suspiljstva [Fragmentary political culture as a manifestation of the transitional period of development of Ukrainian society] (PhD Thesis). Kyjiv: Nac ped. un-t im. M. P. Draghomanova, p. 8.

${ }^{34}$ Karlova V.V. (2013) Nacionaljna samosvidomistj jak dukhovna osnova derzhavotvorchykh procesiv v Ukrajini: upravlinsjkyj aspekt [National consciousness as the spiritual basis of statemaking processes in Ukraine: the administrative aspect] (PhD Thesis). Kyjiv 
emergence of new political parties and public associations indicates the development of civil society and civic initiatives ${ }^{35}$.

The defining concept of political culture was proposed and introduced for the first time by American political scientist G. Almond, who in connection with an attempt to develop a classification for comparing political systems, noted that each political system was included in a specific model of policy orientation. This, according to the scientist, is appropriate to call political culture $^{36}$. Today, the term "political culture" can rightly be called one of the most common and, at the same time, one of the most controversial concepts in science.

From the moment of the emergence of political relations, that is, the institutionalization and alienation of the majority of members of one or another community of management relations, political culture emerges as a specification of the general culture ${ }^{37}$. Political culture is an integral part not only of politics but also of human existence. In the course of historical development, the interaction of culture and politics manifests itself as a dialectic of political, social, cultural processes, and manifests itself differently, depending on the specific efforts of the functioning of a society ${ }^{38}$. Culture is manifested and embodied in political and legal ideas, values, attitudes and institutions, power relations ${ }^{39}$. Political culture is a kind of translation of political experience and reproduction of political life of society, which makes it possible to consider it as the most important characteristic of the political system, which is going through a difficult stage of its development - the stage of democratic transition ${ }^{40}$. Contemporary political culture acts as a means of reproducing the political life of the society, a system of worldviews, orientations, patterns of behaviour of individuals and groups, as well as forms of functioning of political institutions that are manifested in the direct activity

35 Zimina N.V. (2014) Analiz politicheskikh partiy i obshchestvennykh ob'edineniy v partiynykh sistemakh [Analysis of political parties and public associations in party systems]. Vlast', no. 12, p. 63.

${ }^{36}$ Almond G.A. (1956) Comparative Political System. Journal of Politics, no. 18, p. 396.

${ }^{37}$ Duka A.V. (1995) Politicheskaya kul'tura: problemy genezisa i printsipy tipologii [Political culture: problems of genesis and principles of typology] ( $\mathrm{PhD}$ Thesis). Sankt-Peterburg, p. 4.

38 Ovsyannikov Yu.A. (2005) Politicheskaya kul'tura: sotsiokul'turnye osnovy vzaimodeystviya politiki i vlasti [Political culture: socio-cultural foundations of the interaction between politics and power] (PhD Thesis). Rostov-na-Donu: Rostovskiy gosudarstvennyy universitet, p. 6.

${ }^{39}$ Gurevich A.Ya. (1984) Kategorii srednevekovoy kul'tury [Medieval Culture Categories]. Moskva: Iskusstvo, p. 26.

${ }^{40}$ Ishmanova G.D. (2007) Struktura politicheskoy kul'tury i proyavlenie ee komponentov v sotsial'no-politicheskoy zhizni sovremennoy Rossii [The structure of political culture and the manifestation of its components in the socio-political life of modern Russia] (PhD Thesis). Ufa: Bashkirskiy gosudarstvennyy universitet, p. 3 . 
of the subjects of the political process. Political culture has a systemic character at the national level, because it is part of a complex adaptation mechanism of a particular people to the conditions of their own life ${ }^{41}$. The public's positive or negative attitude to decisions made by public authorities depends, among other things, on the level of political culture.

Political culture as part of human culture can change under the influence of changes in the system of values of the culture of society. But the basic values (value bases) change rather slowly, they are little prone to changes, while peripheral values can undergo more frequent changes, be transformed in times of crisis of society, changes of political regimes. Political culture is a fairly conservative element of society's culture. Once formed, political culture remains a stable, integral formation at its core ${ }^{42}$.

Nowadays, politics is becoming increasingly active in the practical life of citizens. Therefore, it is especially important to take into account the place of political culture in public life, its influence on the civic position of the population, etc. Political culture is understood as a qualitative composition of the political life of a society, determined by historical, socio-economic and political conditions and reflects the awareness of the subject - society, group of persons, person - relevant political relations, ways of activity, norms and values, the degree of socio-cultural development of man and the degree of their activity in the transformation of political and social reality ${ }^{43}$. The political culture of civil society must be developed as one of the main conditions for socio-political stability. Involving citizens in the decisionmaking process will help to shape a democratic political culture in Ukraine. In turn, citizens should also understand that the position of removal from politics, which is often observed today in the formation of public authorities, is far from being better on condition that the authorities try to secure a space of self-control and permissiveness.

Analyzing the influence of political culture on the transformation processes of Ukrainian society, Yu. Riaboy concludes that political culture is a set of political values, norms, orientations and ways of behaviour of citizens in relation to politics in general, the political system, as well as their role in

${ }^{41}$ Trebin M. p. ta in. (2013) Ghromadjansjke suspiljstvo: politychni ta socialjno-pravovi problemy rozvytku [Civil society: political and socio-legal problems of development]: monoghrafija. Xarkiv: Pravo, p. 318.

${ }^{42}$ Djomina O.S. (2014) Politychna kuljtura jak cinnisno-normatyvna systema suchasnogho ukrajinsjkogho suspiljstva [Political culture as a value-normative system of modern Ukrainian society]. Naukovyj chasopys NPU imeni M. p. Draghomanova, vol. 15, pp. 150.

${ }^{43}$ Korzh S.A. (2009) Fraghmentarna politychna kuljtura jak vyjav perekhidnogho periodu rozvytku ukrajinsjkogho suspiljstva [Fragmentary political culture as a manifestation of the transitional period of development of Ukrainian society] (PhD Thesis). Kyjiv: Nac ped. un-t im. M.P. Draghomanova, p. 7. 
this system. The scientist also points out that increasing the level of political culture seems to be possible by increasing the openness of the political system, as well as by acquiring it with the ability to react in a timely manner to socio-political transformations; raising ideological and organizational pluralism; creating effective and efficient mechanisms for preventing the violation of citizens' rights; formation of a new adequate time and democratic norms of the political elite; closing the gap between citizens and political power; providing opportunities for real participation of the population in political processes, etc. ${ }^{44}$

Thus, political culture is a multifaceted phenomenon with its historical, social, political, legal and psychological roots. In addition to the fact that political culture is considered one of the indispensable components of the institutions of society, it influences all spheres of both state and public life, it is a system of values that shape the identity of nations, the unity of the state. An analysis of the current state of political culture allows us to find answers to a number of questions that are important for an objective assessment of the progress of reforms, clarification of the strategy and tactics of our country's development.

\section{CONCLUSIONS}

Based on a comprehensive theoretical and legal analysis of the political system of society, we can state the following.

1. The political system of society is a coherent and complex set of elements, the task of which is aimed at achieving and ensuring the stable functioning of society through their effective interaction and exercise of political functions in accordance with the fundamental principles of law. Features of the political system of society are: the integrity and complexity of the elements; conditional independence; internal and external relationships; static and dynamic character; normative regulation. The following is defined: 1) in Ukraine, civil society institutions do not act as full (real) subjects of political and public activity; 2) the national model of political culture as a component of the political system of society has not been formed in society. This causes the social order of Ukraine to be frozen; active participation of the public in the management of public and state affairs will produce renewal and modernization of the political system, emergence of new public and political leaders, formation of citizens' trust in the authorities, strengthening of democracy. Political opposition is a necessary element and factor in the development of an open society, a democratic and rule of law.

44 Rjaboj Yu.O. (2012) Vplyv politychnoji kuljtury na transformacijni procesy ukrajinsjkogho suspiljstva [The influence of political culture on the transformation processes of Ukrainian society] (PhD Thesis). Mykolajiv: Chornomor. derzh. un-t im. Petra Moghyly, p. 5-6. 
2. It is important to develop inter-party cooperation at: 1) internal (between domestic parties) level and 2) external (implies two strategic directions: European parties and parties of other democratic states of the world). The current political system of Ukrainian society is open and requires communication of its subjects with international partners. In today's democratic, social-legal state, the need for the establishment and development of local self-government is due to a number of reasons. Under the conditions of a political system of a democratic society, the territorial communities, which are the basis and the primary subject of local self-government, play an undeniable role, since they ensure its normal and effective functioning.

3. Political culture is the deterministic historical, political, social, psychological, legal influence of the views, values and ideals of a society, group of persons or persons, expressed in the attitude of these subjects to the political process in the country of residence. Political culture must be developed as one of the main conditions for socio-political stability. Involving citizens in the decision-making process will help to shape a democratic political culture in Ukraine. In turn, citizens should also be aware that the position of removal from politics, which is often followed today in the formation of state bodies, is far from being better when the authorities try to secure a space of self-control and permissiveness.

\section{SUMMARY}

The paper deals with the problems of functioning of the political system of society in Ukraine from the standpoint of theoretical and legal science. It is emphasised that the political system of society is a coherent and complex set of elements, the task of which is aimed at achieving and ensuring the stable functioning of society through their effective interaction and implementation of political functions in accordance with the fundamental principles of law. The features of the political system have been identified. It is stressed that in Ukraine civil society institutions do not act as full (real) subjects of political and public activity. It is also noted that the national model of political culture as a component of the political system of society has not been formed in society. It is emphasised that the modern political system of Ukrainian society is open and requires communication of its subjects with international partners. The role of the territorial community in the development of Ukraine's political system is revealed. The definition of political culture is proposed. Political culture must be developed as one of the main conditions for socio-political stability. 


\section{REFERENCES}

1. Mynjkovych-Slobodjanyk O.V. (2015) Pravova ta politychna kuljtura $\mathrm{v}$ umovakh polityko-pravovoji transformaciji suspiljstva [Legal and political culture in the conditions of political and legal transformation of society]. Chasopys Kyjivsjkogho universytetu prava, no. 4, pp. 28-31 [in Ukrainian].

2. Ishmanova G.D. (2007) Struktura politicheskoy kul'tury i proyavlenie ee komponentov v sotsial'no-politicheskoy zhizni sovremennoy Rossii [The structure of political culture and the manifestation of its components in the socio-political life of modern Russia] ( $\mathrm{PhD}$ Thesis). Ufa: Bashkirskiy gosudarstvennyy universitet [in Russian].

3. Nalyvajko L.R. (2009) Derzhavnyj lad Ukrajiny: teoretyko-pravova modelj [State system of Ukraine: theoretical and legal model]: monoghrafija. Kharkiv: Pravo [in Ukrainian].

4. Ghotun A. (2011) Osnovni koncepciji doslidzhennja komunikaciji v politychnij systemi suspiljstva [Basic concepts of communication research in the political system of society]. Politychnyj menedzhment, no. 1, pp. 75-86 [in Ukrainian].

5. Nedbajlo P.O. (1967) Politychna orghanizacija suspiljstva [Political organization of society]. Kyjiv: In-t derzhavy i prava AN Ukrajiny, Naukova dumka [in Ukrainian].

6. Il'inskiy I.P. i dr. (1975) Politicheskaya organizatsiya i upravlenie obshchestvom pri sotsializme [Political organization and management of society under socialism]. Moskva: Mysl' [in Russian].

7. Butko I.P., Kornijenko M.I. (1988) Politychna systema radjansjkogho suspiljstva [The political system of Soviet society]. Kyjiv: Radjansjka shkola [in Ukrainian].

8. Keljman M.S., Murashyn O. Gh., Khoma N.M. (2003) Zaghaljna teorija derzhavy ta prava [General theory of state and law]: pidruchnyk. Ljviv: Novyj svit-2000 [in Ukrainian].

9. Ghoncharov P. K. (2009) Polytycheskaja systema rossyjskogho obshhestva v uslovyjakh postsovetskogho tranzyta: socyologhycheskyj analyz [The Political System of Russian Society in Post-Soviet Transit Conditions: A Sociological Analysis] (PhD Thesis). Moskva: Ros. akad. ghos. Sluzhbы [in Russian].

10. Volynyka K.Gh. (2003) Teorija derzhavy i prava [The theory of state and law]: navch. posib. Kyjiv: MAUP [in Ukrainian].

11. Aznagulova G.M. (2010) O vzaimodeystvii pravovoy i politicheskoy system [On the interaction of legal and political systems]. Yurisprudentsiya, T. 20, vol. 4, pp. 5-15 [in Russian].

12. Jusov A.V. (2008) Politychna systema suchasnogho suspiljstva: ponjattja, struktura, funkciji [The political system of modern society: 
concepts, structure, functions]. Derzhava $i$ pravo. Jurydychni $i$ politychni nauky, vol. 41, pp. 112-116 [in Ukrainian].

13. Nazarenko O. (2012) Politychna systema suspiljstva: sutnistj, osnovni rysy, funkciji [Political system of society: essence, main features, functions]. Visnyk Kyjivsjkogho nacionaljnogho universytetu imeni Tarasa Shevchenka. Jurydychni nauky, vol. 94, pp. 86-90 [in Ukrainian].

14. Grin'ko V.V. (2006) Sotsial'no-politicheskaya sistema obshchestva kak elektoral'naya model' [Socio-political system of society as an electoral model]. Sotsiologiya vlasti, no. 3, pp. 149-157 [in Russian].

15. Vidomosti z sajtu Ministerstva justyciji Ukrajiny [Information from the website of the Ministry of Justice of Ukraine] https://minjust.gov.ua/m/4561 [in Ukrainian]

16. Jakymenko Ju., Bychenko A., Zamjatin V. ta in. Ukrajina 2016-2017: oznaky proghresu ta symptomy rozcharuvannja (analitychni ocinky) [Ukraine 2016-2017: signs of progress and symptoms of disappointment (analytical estimates)]. Kyjiv [in Ukrainian].

17. Morarj M.V. (2017) Politychna opozycija jak nevid'jemnyj element politychnoji systemy suspiljstva [Political opposition as an integral part of the political system of society]. Ghileja, vol. 118, pp. 323-326 [in Ukrainian].

18. Mykhaljchenko M., Kuras I., Rudych F.ta in. (2002) Vzajemodija politychnoji vlady i opozyciji jak politologhichna problema [The interaction of political power and opposition as a political problem]. Suchasna ukrajinsjka polityka i politologhija pro neji. Kyjiv: In-t derzhavy i prava im. V.M. Korecjkogho, pp. 20-33 [in Ukrainian].

19. Chernoivanenko A. V. (2016) Funkcionuvannja politychnykh partij v Ukrajini: osoblyvosti normatyvno-pravovogho zabezpechennja [Functioning of political parties in Ukraine: features of normative legal support]. Teorija ta praktyka derzhavnogho upravlinnja, vol. 3, pp. 67-74 [in Ukrainian].

20. Zakon pro finansuvannja politychnykh partij iz derzhavnogho bjudzhetu [Law "On financing political parties from the state budget"] https://uk.wikipedia.org/wiki/Закон_про_фінансування_політичних_партій_ із_державного_бюджету [in Ukrainian]

21. Derzhavne finansuvannja partij: pljusy ta ryzyky [Public party funding: benefits and risks] https://antikor.com.ua/articles/59246-derhavne_ finansuvannja_partij_pljusi_ta_riziki [in Ukrainian]

22. Rivenj doviry do suspiljnykh instytutiv ta elektoraljni orijentaciji ghromadjan Ukrajiny [The level of trust in public institutions and the electoral orientation of Ukrainian citizens] http://razumkov.org.ua/napriamky/ sotsiologichni-doslidzhennia/riven-doviry-do-suspilnykh-instytutiv-ta-elektoralnioriientatsii-gromadian-ukrainy-2 [in Ukrainian] 
23. Partijno-ideologhichna strukturyzacija jevropejsjkogho politychnogho prostoru ta mozhlyvosti prosuvannja interesiv Ukrajiny $\mathrm{v}$ JeS [Partyideological structuring of the European political space and opportunities for promoting Ukraine's interests in the EU] http://www.niss.gov.ua/articles/693/ [in Ukrainian]

24. Trebin M.P. ta in. (2013) Ghromadjansjke suspiljstvo: politychni ta socialjno-pravovi problemy rozvytku [Civil society: political and socio-legal problems of development]: monoghrafija. Xarkiv: Pravo [in Ukrainian].

25. Baranovsjka T.M. (2017) Derzhavna polityka rozvytku terytorialjnykh ghromad v Ukrajini [State Policy for Development of Territorial Communities in Ukraine] (PhD Thesis). Kharkiv: Nacionaljna akademija derzhavnogho upravlinnja pry Prezydentovi Ukrajiny [in Ukrainian].

26. Nacionaljna strateghija spryjannja rozvytku ghromadjansjkogho suspiljstva v Ukrajini na 2016-2020 roky [National Strategy for Promoting Civil Society Development in Ukraine for 2016-2020]:Ukaz Prezydenta Ukrajiny vid 26 ljutogho 2016 r. Oficijnyj visnyk Prezydenta Ukrajiny, 2016, no. 7 [in Ukrainian].

27. Pro vnutrishnje ta zovnishnje stanovyshhe Ukrajiny v 2013 roci [On the internal and external situation of Ukraine in 2013]: Shhorichne Poslannja Prezydenta Ukrajiny do Verkhovnoji Rady Ukrajiny. Kyjiv : NISD, 2012 [in Ukrainian].

28. Djomina O.S. (2014) Politychna kuljtura jak cinnisno-normatyvna systema suchasnogho ukrajinsjkogho suspiljstva [Political culture as a valuenormative system of modern Ukrainian society]. Naukovyj chasopys NPU imeni M.P. Draghomanova, vol. 15, pp. 148-155 [in Ukrainian].

29. Karlova V.V. (2013) Nacionaljna samosvidomistj jak dukhovna osnova derzhavotvorchykh procesiv $v$ Ukrajini: upravlinsjkyj aspekt [National consciousness as the spiritual basis of state-making processes in Ukraine: the administrative aspect] (PhD Thesis). Kyjiv [in Ukrainian].

30.Zimina N.V. (2014) Analiz politicheskikh partiy i obshchestvennykh ob"edineniy v partiynykh sistemakh [Analysis of political parties and public associations in party systems]. Vlast', no. 12, pp. 62-64 [in Russian].

31. Almond G.A. (1956) Comparative Political System. Journal of Politics, no. 18, p. 394-409.

32. Duka A.V. (1995) Politicheskaya kul'tura: problemy genezisa i printsipy tipologii [Political culture: problems of genesis and principles of typology] (PhD Thesis). Sankt-Peterburg [in Russian].

33. Ovsyannikov Yu.A. (2005) Politicheskaya kul'tura: sotsiokul'turnye osnovy vzaimodeystviya politiki i vlasti [Political culture: socio-cultural foundations of the interaction between politics and power] ( $\mathrm{PhD}$ Thesis). Rostov-na-Donu: Rostovskiy gosudarstvennyy universitet [in Russian]. 
34. Gurevich A. Ya. (1984) Kategorii srednevekovoy kul'tury [Medieval Culture Categories]. Moskva: Iskusstvo [in Russian].

35. Korzh S. A. (2009) Fraghmentarna politychna kuljtura jak vyjav perekhidnogho periodu rozvytku ukrajinsjkogho suspiljstva [Fragmentary political culture as a manifestation of the transitional period of development of Ukrainian society] (PhD Thesis). Kyjiv: Nac ped. un-t im. M.P. Draghomanova [in Ukrainian].

36. Rjaboj Yu.O. (2012) Vplyv politychnoji kuljtury na transformacijni procesy ukrajinsjkogho suspiljstva [The influence of political culture on the transformation processes of Ukrainian society] ( $\mathrm{PhD}$ Thesis). Mykolajiv: Chornomor. derzh. un-t im. Petra Moghyly [in Ukrainian].

Information about the author: Chepik-Trehubenko Olha,

Candidate of Law, Associate Professor at the Department of General Legal Disciplines, Dnipropetrovsk State University of Internal Affairs 26, Gagarina Ave, Dnipro, Ukraine ORCID ID: orcid.org/0000-0001-5499-5793 